jobs while laying the foundation for a cleaner, more competitive economy. The trick, he says, will be getting the bill through Congress and then sustaining funding into the future.

"We hope that this gets built into the base and that it is essentially front-loading some of the increases that are planned for 2010 and beyond," says Berdahl. Obama is scheduled to present his proposed budget for fiscal year 2010 in early February.

But some have questioned whether the one-time infusion of cash will matter much to agencies whose budgets have flatlined or been lower than expected in recent years. Elias Zerhouni, former director of the $\mathrm{NIH}$, says the stimulus package does not focus enough on sustaining scientists, concentrating instead on the facilities that house them. The current proposal "is too timid and not strategic enough in addressing the long term", he says. "It's short-term wise but long-term ineffective."

Democratic congressional leaders, spearheaded by House Speaker Nancy Pelosi of California, developed the bill in consultation with Obama's transition team. Although the legislation is sure to change as it moves through the House and the Senate, the fact that it has the tacit approval of both Pelosi and Obama means that it is likely to survive in some form. Republicans, however, were not consulted.

Most of the stimulus spending would extend over two years, although money for peer-reviewed grants must be awarded within 120 days to ensure it is spent quickly. That could mean that agencies use the money to fund peer-reviewed grants that previously scored highly but were not funded because of a lack of money at the time. At the NSF, individual directorates are likely to be allowed to determine how they will spend the \$2-billion windfall. Other chunks have been designated for specific programmes: $\$ 400$ million, for instance, will go to the major research equipment and facilities programme, which includes large projects that must be approved by the National Science Board. Another \$500 million will go to instrumentation, including modernization and retrofitting.

At NASA, the $\$ 400$ million targeted for the science office includes $\$ 250$ million to accelerate Earth-sciences projects recommended in a recent prioritization survey by the National
Academies. Among other things, that would pay for a climate sensor measuring total solar irradiance to be put back on the next generation of US weather satellites; it had previously been removed to save money.

Bart Gordon (Democrat, Tennessee), chairman of the House Science Committee, called the bill a long-delayed down payment on the American Competitiveness Initiative, which seeks to boost research and education in mathematics, engineering and the physical sciences.

Neal Lane, a professor at Rice University in Houston, Texas, and a former science adviser to President Bill Clinton, says agencies such as the NSF and the Department of Energy will probably be able to absorb and spend the additional funding quickly, in part because they have been planning for increased funding under the competitiveness initiative. The NSF in particular has been faced with a backlog of requests and peerreviewed proposals for facilities and construction of major research equipment. "Those seem like reasonable places to make a quick and early investment," he says. "The researchers out there could actually spend a lot of money wisely and quickly if it were made available to them." Jeff Tollefson; additional reporting by Meredith Wadman and Rich Monastersky. monkeys. Further pathology tests are due to begin in spring at the Australian Animal Health Laboratory in Geelong, Victoria.

The infected pigs came from several farms on the island of Luzon, and on 13 January, health officials collected blood and tissue samples from hundreds of apparently healthy pigs there. Although Rollin does not expect to find the virus itself in these samples, the pigs may carry antibodies that should indicate an approximate mortality rate associated with exposure.

Rollin suspects that, as is the case with monkeys, the infections resulted from contact with a reservoir of the virus, rather than spreading from animal to animal. In 2005, outbreaks of human Ebola in Gabon and the Republic of the Congo were traced back to colonies of bats (E. M. Leroy et al. Nature 438, 575-576; 2005). "It's almost certainly the case [in the Philippines]," says Rollin.

The virus is likely to be spread by bat droppings falling into the pigs' feed, and the threat of infection could be reduced by moving fruit trees, where the bats roost, away from pig farms, or by putting roofs on pig enclosures. "We can't exterminate it, we just have to learn how to avoid it," says Rollin. David Cyranoski

\title{
GRAPHIC DETAIL Prices plummet on carbon market
}

The price of European Union (EU) allowances for carbon dioxide emissions has reached an all-time low, hit by falling oil and gas prices, and expectations that economic recession will lead to reduced energy demand.

Under the EU's mandatory emission trading system - set up in 2005 and still by far the largest such scheme in the world - power plants and other $\mathrm{CO}_{2}$-intensive industries can buy emission allowances that allow them to exceed their government-allocated $\mathrm{CO}_{2}$ caps. In 2008, the equivalent of almost 5 billion tonnes of $\mathrm{CO}_{2}$ was traded on the global market, an 83\% rise on 2007.

At close of trading on

19 January, allowances to emit one extra tonne of $\mathrm{CO}_{2}$ in 2009 were selling at just $€ 11.65$ (US\$15.32) on European exchanges that

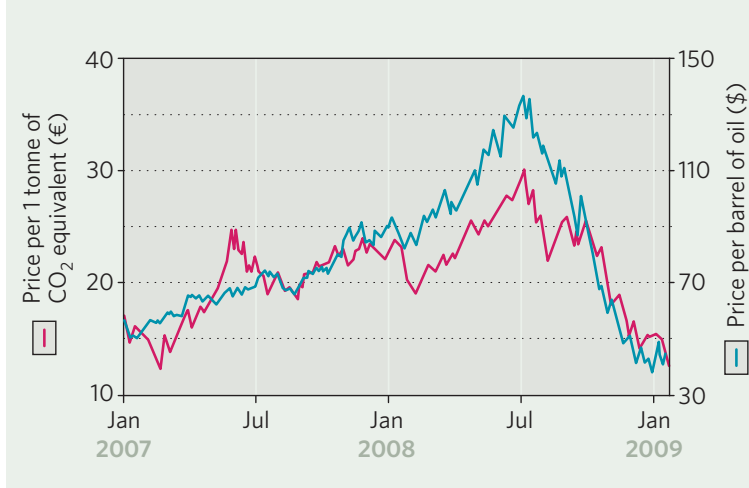

trade carbon, such as the European Energy Exchange (EEX) in Leipzig, Germany (see graph). The price of allowances saw a recent peak of above $€ 30$ in July 2008, but falling oil and gas prices have encouraged electricity generators to switch from burning coal to cleaner natural gas, reducing demand for emission allowances
Given the dire economic outlook, analysts believe that it will be difficult to stop the market's negative trend in the next few months.

The EU's emission trading system is due to be reformed in 2013 to reduce the amount of free allowances handed out to companies (see Nature 456, 847; 2008).

Quirin Schiermeier 